Бојана Требињац

УДК 02:004.738.5

Универзитет у Београду

ДОИ https://doi.org/10.18485/

Фиолошки факутет

melissa.2016.15.2.ch14

\title{
УЛОГА ВИРТУЕЛНИХ БИБЛИОТЕКА У ПРОЦЕСУ УЧЕЊА
}

\section{Сажетак}

Напредак у дигиталним технологијама и даље играју кључну улогу у обликовању будућности библиотека. Сада, већина библиотеке су задржале своје виртуелне присуство као додатак физичком присуству. Скоро све библиотеке имају привлачан и разрађен сајт. У библиотечко-информационој делатности различити термини користе се да опишу виртуалне библиотеке: дигиталне библиотеке, електронске библиотеке, е-библиотеке, као и шири појам виртуелне библиотеке. Термин виртуелна библиотека се користи да опише управљање колекцијама извора информација у електронском формату - текст, слике, аудио, видео, мултимедија. Стога, виртуелне библиотеке могу укључити дигиталне колекције књига, новина, фотодокумента, картографску грађу, нотну грађу, звучне књиге. Овај рад истражује предности виртуелних библиотека за учењу, типови учења које могу бити подржани у виртуелним окружењима библиотека, значај дизајна како би се омогућио приступ различитим типовима учења, као и проблеми које намећу виртуелне библиотеке.

Кључне речи: виртуелне библиотеке, дигиталне библиотеке, дигиталне збирке, процес учења, е-учење, технологијом побољшано учење

\section{Увод}

Мисија библиотеке може се једноставно објаснити као омогућавање услуга неопходних корисницима. Ову мисију деле све библиотеке у свакој генерацији и у целом свету. До скора се мисији библиотеке приступало на традиционалан начин, а данас се за њено испуњавање очекују: сарадња, интерактивност, интердисциплинарност, мултифункционалност, мултимедијалност, динамичност, брзина, доступност, претраживост, те скуп ових особина и активности наводи савремене теоретичаре да такву библиотеку назову виртуелном 
или постмодерном. Библиотека већ данас, а временом ће то бити све више, излази из оквира централизоване, физички омеђене, статичке, формално организоване јединице и добија епитете проблемски оријентисане, технолошки напредне, удруживању захваљујући финансијски неспутане, ефикасне и професионалне институције.

Технолошки напредак сигурно није проузроковао појављивање конзорцијума (који су као облик удруживања познати у привреди, економији и образовању још од средине 19. века), али их деведесетих година јесте олакшао, убрзао и допринео распрострањености и комплексности њиховог пословања. Библиотека 21. века наликоваће, ако јој то допустимо, на самоуслуге информација. Предност је у њеној демократичности и отворености, слободи приступа разнородним подацима, наговештеним у спознаји самоуслуге, недостатак у чињеници да се често нуди пласирање не знања, већ информација, са веком трајања условљеним економским, политичким и другим друштвеним законитостима. Информација може бити самостална, док знање захтева контекст; информација може бити брза, а знање се стиче споро. Чини се да је интернет овладао светом. Интернет почива на снази идеја и, након прве фазе свога развоја директно зависне од безбедносног система, у другој фази, пре његове комерцијализације, он, како добро знамо, између осталог почива и на научним садржајима, испуњавању универзитетских потреба и међунаучној комуникацији.

Библиотекарство, с једне, информационе науке, с друге стране; традиционални облици организације и пословања наспрам глобализације информација којој доприноси њихова дигитална форма, и скоро наднаравних и надтипских облика удруживања у циљу комплекснијег информисања; економски и политички утицаји на друштвени положај библиотека и дигитализовање информација као предуслов учења на даљину и глобализације знања - супротности су међу којима су се данас обрели и библиотекари и корисници. Међусобно се сустижући и престижући, електронске, виртуелне и дигиталне библиотеке носе реалне разлике, али су све оне синоним брзог информисања, које не познаје националне, географске и историјске границе, већ се битно темељи на оним економским. Суштина и традиционалних и дигиталних библиотека јесте интелектуал- 
ни производ, а не његова дигитална форма, јесте педантан библиографски податак и нормативна датотека, а не колекција бита, јесте брига за једноставно складиштење, укрштено сортирање и правовремено презентирање свих података. Дигитализовани облик заправо је сурогат оригинала, настао са жељом да се запамти његова тренутна слика, како му спољни утицаји не би могли наудити, као и да се отвори, у просторном, временском, правном смислу коришћење тога примерка. Информативност, атрактивност, претраживост и легалност треба да буду општи квалитети дигиталне библиотеке.

\section{Дигитална - електронска - виртуелна библиотека}

У ширем историјском смислу, термин виртуелне библиотеке постао је тренд средином деведесетих година прошлог века, али никада није ухватио професионалну употребу у формалном смислу да би повезао оперативну дефиницију као и фраза дигиталне библиотеке. Затим, термини дигиталне библиотеке, електронске библиотеке и виртуелне библиотеке често су коришћени наизменично. Критично, појам дигиталне библиотеке настао је и развио се у оквиру широке библиотечке заједнице крајем 1960-их. Током тог периода, многе академске библиотеке покренуле су иновативне дугорочне пројекте како би олакшале приступ њиховим непрестано растућим колекцијама. Ови програми интегришу нове информационе технологије са традиционалним штампаним материјалима, чинећи библиотеке међу првим корисницима алтернативних медија као што су микрофилмови, аудиотраке и други звучни записи и електронски фајлови - сви претходници данашњих онлине комерцијалних система базе података и збирних дигиталних колекција. Данас термин дигиталне библиотеке, када се користи у овом ширем смислу, преовладао је у смислу заједничке употребе. Виртуелна библиотека је, међутим, све више израз популарног избора када се ради о агрегираним дигиталним ресурсима за учење и библиотекарским услугама које подржавају наставни план и програм који нуде универзитети. Иако нема граница о величини, садржају или релативној вредности података који студенту 
пружа виртуелна библиотека, њена дефиниција је увек обликована педагошким потребама и очекивањима за учење. Данас је термин виртуелне библиотеке скоро увек повезан са библиотечким услугама подршке које су понуђене студентима и факултетима.

Виртуелна библиотека је збирка ресурса доступнихнаједном или више рачунарских система, где је обезбеђен појединачни интерфејс или улазна тачка за збирке. Кључна тачка је да корисници не требају знати где се одређени извори налазе и формирају, већ дакорисник добија потребне информације, локација је „виртуелна“. Грађевински блокови виртуелних иблиотека су дигитална колекција, URL веб страница, дигитализовани ресурси, створени дигитални ресурси, додатне технологије за виртуелне библиотеке као што су веб дизајн, HTML, језици, веб сервери, сервери за складиштење информација итд. Виртуелна библиотека библиотека која постоји, без обзира на физички простор или локацију. То је технолошки начин повезивања ресурса различитих библиотека и информационих сервиса, како унутрашњег, тако и спољног, на једном месту, тако да корисници могу пронаћи оно што им треба брзо и лако.

Виртуелне библиотеке су бибилотеке у којима се нагласак ставља на приступ документима и на пружање информационих услуга - за разлику од традиционалних библиотека, у којима су најважније библиотечка зграда и томови публикација. Сврха им је, међутим иста: и дигиталне и традиционалне библиотеке треба да пруже подршку корисницима у претраживању, налажењу и прибављању докумената, али организација првих треба да буде усмерена више на услуге него на физички простор. Најзначајнији елемент о којем треба водити рачуна при креирању, имплементацији и менаџменту дигиталне библиотеке јесте њена отвореност за сарадњу и повезивање са другим библиотекама у виртуелном простору. Само кроз заједничку расподелу свих ресурса више различитих библиотека, могуће је адекватно задовољење корисничких потреба. Традиционалне библиотеке бирају, чувају и испоручују информације. Све те функције задржавају и нове дигиталне библиотеке, с тим што је селекција све више заснована на принципу „на захтев корисника“, што чување информација може да буде и изван одређеног ограниченог простора, а испорука 
електронска. Сви ти нови елементи захтевају и вештије кориснике, тако да све више пажње треба усмеравати управо на обуку корисника. Квалитет библиотека више се неће мерити „метрима полица или књига", већ пре свега квалитетом пружених услуга. Виртуелне библиотеке све своје ресурсе треба да усмере на задовољавање потреба корисника, а не на набавку докумената.

\section{Појам виртуелних окружења}

Виртуелна окружења су нам омогућили да будемо уметнути у просторима који дају високо друштвено присуство, решавање проблема, интерактивна, изненађујуће пријатна и нове врсте искустава. Виртуелна окружења нуде много потенцијла, користе импресивну технологију, ангажују људске перцептивне и способноси на начине немогуће уз помоћ других техника. Нуде могућност вежбања задатка у виртуелном свету на такав начин да вештине могу да се пренесу у реалном свету као и прилику за богатији ангажман за примену и комуникацију са другим корисницима. Виртуелно окружење (engl. Virtual Environment - VE) се обично описује као облик интеракције између човека и рачунара ( $\mathrm{HCl}$ - engl. Human-computer interaction) која се састоји од рачунарско генерисане визуелне и аудио симулације у тродимензионалном простору (тј. ЗД графици), у којем корисници имају интерактивна искуства (тј. они комуницирају једни с другима и/или имају способност реаговања на доживљаје у околини или чак могућност измене тих естетских доживљаја околине, као што су контрола кретања аватар или променом неке карактеристике околине) (Hermosa and Andy 2009). Често се и називају и виртуелна реалнност, виртуелни пејзаж, виртуелни простор или виртуелни свет.

Подржавање присуства више корисника је основана намена вирутелних окужења. Већина виртуелних окружења је базирана на једноставним централним серверима. У циљу размене виртуелних светова преко Интернета два основна захтеви су пренос садржаја светова до појединачних учесника и дистрибуција свих промене које су направљене на тим садржајима. У колаборативним виртуелним 
окружењима додатне услуге ће можда бити потребне. У циљу подршке сарадње између учесника, стреаминг аудио и видео садржаја се могу вршити између неких или свих учесника. Развој Интернета, мултимедијалне технологије, база података и других информационокомуникационих технологија (engl. Information and communications technology - ICT) омогућили су постојање виртуелних библиотека. Дигитална технологија увела је промене у начину очувања библиотечких колекција, а тиме и у начин њиховог приказа (Hermosa and Andy 2009). Виртуелне библиотеке чини колекција дигитализованих књига,часописа, магазина, новинских чланака, слика, цртежа, фотографија, звучних и видео записа и разних музејских предмета који у физичком свету нису повезани местом на којем се налазе али су на неки начин повезани са контекстом реалне баштине на коју упућују.

\section{Примена виртуелних окружења у електронском учењу}

Окружења за електронско учење се јављају у различитим варијантама. Најчешће варијанте окружења е-учење су:

- Weб засновани системи за обуку (engl. Web Based Training Systems - WBT),

- Системи за управљање садржајем учења (engl. Learning Content Management Systems - LCMS),

- Платформе за управљање учењем (engl. Learning Management Platforms - LMP),

- Системи за управљање учењем (engl. Learning Management Systems -LMS),

- Виртуелна окружења за учење (engl. Virtual Learning Environments - VLE).

Посматрањем актуелног стања конфигурација система за е-учење примећује се да се у фокусу налазе системи за управљање учењем, системи за управљање садржајем учења и системи за управљање курсевима. Окружења у виртуелним световима може да се користи као дигитална учионица, виртуелно место за одржавање предавања, које може да изгледа као традиционално лицем у лице (engl. face-to-face) 
предавање. Јасно је да се виртуелни светови могу користити на различите иновативне начине. Такође, могу да обезбеде окружење за активности играња улога с циљем уживљавање у додељену улогу и визуелно беспрекоране ЗД симулације (Korićanin 2012).

\section{Услуге дигиталних библиотека}

Виртуелна библиотека креира виртуелне библиографске и документарне услуге за студенте, предаваче и истраживаче. Уз традиционалне услуге (позајмица, проналажење документа, електронску дистрибуцију сажетака из часописа итд.), који се прилагођавају потребама виртуелног корисника, развијене су и друге услуге чија је главна карактеристика прилагођена, редовно се ажурирају и они су „пуш“ услуге, другим речима, корисник их прима персонално у свом поштанском сандучету.

\section{Виртуелна референтна услуга}

У виртуелном референтном сервису, осим што помажу корисницима лично или путем телефонских начина, библиотекари сада развијају садржаје који се лако могу преносити и читати у мобилним телефонима и другим мобилним уређајима како би корисницима помогли у било ком тренутку. Према (Pinto \& Manson, 2012) “Виртуелна референтна услуга је услуга која на основу искустава традиционалних услуга развијених у окружењу информационих технологија задовољава потребе корисника и знања на интерактиван, партиципативни, прилагођени и колаборативни начин".

\section{Библиотека 3.0}

Библиотека 3.0 захтева библиотекаре са вештинама да се баве овим технологијама. (Sav \& Todd, 2007) наводи да је "Библиотека 3.0 
управо иза угла - па који су критеријуми за избор радника Библиотеке 3.0?". Овај рад је представљен на 73. генералној конференцији и савету ИФЛА. Писци истражују питања и изазове у складу са новим технологијама и трендовима који ће се појавити у Библиотеци 3.0, и пита како библиотеке могу учити из других услужних делатности и како ће библиотекари наставити са специфичним вештинама предмета. Писци су започели са информацијама о библиотеки 3.0 и информацијама о библиотекару 3.0. Библиотеке морају осигурати да је њихово библиотекарство спремно за библиотеку 3.0. Затим разговарају о библиотекама Библиотеке 3.0. Путовање у Библиотеку 3.0 ће захтевати неке "возаче", како они мисле. Ови управљачки програми су: технологија, понашање корисника и радно место. У Библиотеци 3.0 не само да пружају услуге људима, већ и корисницима пружају разне услуге. Требали би знати како добити тражене информације и учинити их доступним кориснику без бриге о локацији. Такође би требали помоћи корисницима да користе наведене податке. Библиотекари ће морати радити на алтернативном начину пружања информација уколико један начин комуникације не успе. Тада (Sav \& Todd, 2007) прешло је до препрека за промјене. Након тога, помињу неке информације о томе како се спремити за библиотеку 3.0. Библиотекари или особље библиотеке будућности ће морати бити спремни за целоживотно учење. Неко библиотечко особље можда није обучено за библиотеку, па ће стални професионални развој бити део њиховог свакодневног рада.

\section{Корисник генерише садржај}

Дио снаге семантичког веба за библиотеке је то што корисницима библиотеке омогућавају сами себе да постану ресурси. Библиотека ОРАС / вебсајт је раније била један-на-један искуство, али сада може бити интеракција «многих до многих». Према (Burke, 2009) семантички веб претвара веб странице да буду читљиви и приказани од стране компјутера како би их разумели рачунари. На основу (Rah \& Gul \& Wani, 2010) семантички веб (такође назван Веб 3.0) почиње да оснажује и 
енергише садржај на вебу, а његови основни принципи и технологије могу да подстакну и унапреде дуготрајну дисциплину управљања знањем. Студија се развија у моделски веб систем за управљање знањем који служи за потребе корисника у овом бит и свету бајта. Библиотеке, као и друге организације, могу имати користи од семантичких веб иницијатива. Семантичка мрежа омогућава особи или рачунару да започне у једној бази података, а затим се креће кроз бесконачни скуп повезаних база података. Уместо само идентификације кључних речи и израза, семантички веб се концентрише на идентификацију значења садржаја. Овај технички документ пружа информације о томе како користити менаџмент знања како би пружили добре услуге корисницима. (Bosque \& Leif \& Skarl, 2012) наводи да је Twitter платформа за друштвене мреже која корисницима омогућава емитовање кратких порука од највише 140 карактера. Овакво ограничење ствара потребу за брзим, до тачним порукама које морају бити потресне, али и информативне. Овај рад је преглед како библиотеке користе Твитер у академском окружењу. Постоји велики потенцијал да се повећа употреба технологије друштвених медија. Библиотеке могу имати користи од садржаја направљеног од стране корисника.

\section{Мобилне библиотеке}

Библиотека 3.0 ће академским библиотекама пружити могућност да буду у џепу ученика. Данашњи студенти увек користе мобилну технологију. Потребно је видети веб локацију библиотеке са димензијама мобилног екрана. Према (Wilson \& McCarthy, 2010) мобилна револуција је на нас. Библиотека мора да се креће ка мобилном развоју. Интернет корисници. Библиотеке морају припремити стратешки план за кориштење мобилне библиотеке за пласирање својих услуга. (Wilson \& McCarthy, 2010) илуструје како се услуге библиотеке могу прилагодити мобилном окружењу и како библиотека може играти улогу у ширим кампусним мобилним иницијативама. Овај папир је добар ресурс за библиотеке да започну своју мобилну библиотеку. Писци пружају неке сјајне информације и примере за 
мобилну библиотеку. (Cummings \& Merrill \& Borrelli, 2010) каже да су “библиотечке услуге промењене са трансформацијама у рачунарству и умрежавању". Повећане су употребе ручних мобилних рачунарских уређаја као што су веб-омогућени мобилни телефони. Библиотеке морају истражити свој утицај на њихову наплату и услуге које пружају. Овај рад пружа информације о природи ручне мобилне рачунарске употребе од стране академске библиотеке и да утврди да ли постоји значајна потражња за кориштењем библиотечких услуга са овим малим екранским уређајима.

\section{Услуга кратких порука (CMC)}

Када нема интернета, СМС је најбољи алат за познавање библиотечких услуга. (Франтз \& Туцкер-Раимонд, 2011) каже да «СМС постаје алат који широко користи библиотека у пружању референтних услуга». Овај рад говори о јединственој природи текстуалних порука. Пружа неке СМС програме и веб странице. СМС је одлично решење за студенте. Студенти могу да користе СМС да би добили информације о локацији библиотеке, радном времену или доступним услугама. Текст библиотекар је одличан алат у којем патроне могу добити информације о библиотеци.

\section{Облак}

Библиотека 3.0 захтева високе технолошке алате и особље. Цлоуд цомпутинг је најбољи за библиотеке који не могу приуштити технологију и особље. Према (Yang, 2012) цлоуд цомпутинг спада у неколико познатих категорија: софтвер као услуга (SaaS), хардвер као услуга (HaaS) или платформа као услуга (PaaS) и инфраструктура као услуга (laaS). Писац почиње са дефинисати шта је цлоуд цомпутинг. Онда помиње врсте цлоуд цомпутинга. Онда је прешао на предности и мане цлоуд цомпутинга. После тога смо се преселили да дискутујемо о употреби рачунара у облаку у библиотекама. „Нова 
генерација ИЛС базираних на облаку дозвољава многим библиотекама да деле корисне податке".

Облак је нова генерација информационих технологија. Облак, познат и под називом „The Cloud“ (Pomero, 2012), представља високо скалабилну платформу која обећава брз приступ хардверу и софтверу преко Интернета, поред лаког управљања и приступа од стране нестручних корисника. У чланку су описане карактеристике Клауда, како се може користити у професионалном окружењу, као и његове предности и недостаци. Писац пружа информације о недостацима које сваки библиотекар мора знати прије преласка на облак. Библиотеке ће имати користи од цлоуд цомпутинга и његових карактеристика.

\section{ГеоТагинг (GeoTagging)}

Геотагинг помаже корисницима да пронађу одређене информације лоциране на одређеној локацији. Тито Сиера и Маркус Вуст, из Библиотеки Универзитета у Сјеверној Каролини успели су направити виртуалну кампусну туру користећи географско означавање (означавање одређених локација на мапи) и геолокација технологије. „Библиотекари морају да користе нове и предстојеће технологије како би стигли до ученика двадесет првог века“, што аутор препоручује (Urban, 2010).

\section{Персонализоване библиотеке у виртуелним окружењима}

Библиотека допуњује документарну акцију кроз развој пројеката за сваку врсту студентских корисника, предавача, менаџера и истраживача. Основне предности које виртуалност нуди у развоју библиотека-документарних центара су то што омогућавају увођење библиотечких услуга у окружења која нису типична за библиотеку. Ово омогућава развој „прилагођених библиотека“ за сваку врсту корисника. Основно ћемо се фокусирати на пројекте развијене у циљу учења и наставе, иако ћемо споменути и програме који су у току на 
располагању менаџменту и истраживању. У овој фази развоја, библиотека је присутна на следећим локацијама:

- у стварној библиотеци;

- унутар учионице, поред сваког предмета;

- у простору посвећеном пружању подршке предавачима;

- у простору у коме руководеће особље међусобно комуницира;

- на веб сајту креирану ради истраживања и докторских студија;

Нова библиотека не преноси само информације, већ укључује и нови аспект као генератор и дистрибутер информација. Овај нови аспект предвиђа генерисање и/или очување докумената који у неким случајевима представљају дио наставних материјала, а у неким другим су комплементарни са њима (Kaur 2015).

\section{Предности и недостаци виртуелних библиотека при учењу}

Изградња виртуелне библиотеке захтева разматрање предности и недостатака у циљу стварања ефикасне библиотеке. Са квалитетним дизајном и подршком квалификованих стручњака за информисање, виртуелне библиотеке могу пружити моћно окружење за учење.

Предности примене виртуелних библиотека у е-учењу су:

1. Непосредан приступ ресурсима - виртуелне библиотеке су доступне у било ком тренутку у циљу лакшег учења,

2. Информације одмах ажуриране - одговори на тренутне потребе наставника пружају у кратком року ресурсне информације са најновијим информацијама,

3. Нема физичких граница - људи из целог света могу приступити информацијама све док постоји интернет веза,

4. Подржати различите стилове учења - приступ материјалу у различитим форматима прилагођеним карактеристикама ученика или заједнице ученика; распон ресурса за задовољавање потреба различитих корисника може се прилагодити одређеним школама, разредима и предметима,

5. Доступан за особе са инвалидитетом - нуди алтернативу онима који имају физичке потешкоће у приступу ресурсима у редовној библиотеци користећи аудио и видео, ресурси су доступни визуелно 
и оштећеним слухом; интегришу глас, видео и текст за кориснике који учествују у даљинском образовању,

6. Алат за учење за информациону писменост - омогућава ученицима да лакше проналазе пут око различитих избора претраживања као инструктивног алата, уче вештине избора и коришћења одговарајућих претраживача, читања URL-ова и начина коришћења онлајн базе података,

7. Могућности умрежавања - једна дигитална библиотека може да обезбеди везу са другим ресурсима других дигиталних библиотека,

8. Усмерава студенте на одговарајуће ресурсе - ученици проводе више времена размишљају о информацијама, а не учествују у потрази за временом који допуњују ресурсе за штампање библиотеке; ресурса изабраних за усклађивање тема истраживања, старости и нивоа читања студената.

9. Коришћење рачунарских игара, и игра у опште, за образовне сврхе нуди различите презентације знања и ствара прилике за примену знања у виртуелном свету, чиме се подржава и олакшава процесе учења,

10. Различити облици рада омогућвају боље упознавање својих колега и на тај начин се добија увид у различита решења и различита мишљења на дати проблем.

Када је реч о недостацима примене виртуелних библиотека у образовању, један од главних недостака јесте неопходан приступ рачунару и интернет, као и проблем узроковани недовољним познавањем технологија за приступ виртуелним окружењима. Студенти могу сматрати да услед недовољним позвањем технологије неће моћи да остваре добре резултате и тиме ће можда настојати да избегну коришћење таквих технологија и алата. Такође, један од недостатака јесте и губитак људског контакта, говора тела (невербалне комуникације) и појава неразумевања. Иако ће студент комуницирати посредством аватара, не може се очекивати да ће се аватри понашати као и људи у реалном свету, да ће правити исте гестове и начине понашања. 


\section{Закључак}

На крају можемо закључити да су виртуелне библиотеке нова визија библиотека будућности. Развој виртуелних библиотека ће се одржати кад се библиотеке трансформишу у тродимензионалне електронске информационе центаре. То ће бити могуће када се складиштење података, представљање података и технологија обраде слике напредује да се носе са великим количинама графички представљених података.

Сврха виртуелних библиотека је да подупире учење и стицање знања, да обезбеди солидну основу за образовање и да побољша квалитет живота ослањајући се на дигитално доступне материјале. Виртуална библиотека пружа приступ различитим наставним плановима и програмима, књигама, часописима, новинама, аудио и видео снимцима на националном и међународном нивоу. Виртуелне библиотеке, као ефикасно едукативно средство у јавној служби, мора да пружа подршку корисницим, пружајући прецизне, поуздане иинформације, да одговори на потребе корисника и обезбеди приступ за потенцијалне кориснике (студенате, професоре, истраживаче и академике).

\section{Литертура}

Ball, D. „Positioning librarians as essential to the new Virtual Learning Environments“. Proceedings 27th Annual International Association of Technological University Libraries, Porto (Portugal), 2006.

Cummings, J. \& Merrill, A., \& Borrelli, S. "The use of handheld mobile devices: their impact and implications for library services". Library Hi Tech, 28.1(2010), 22 - 40.

Evans, W. Building Library 3.0: Issues in Creating a Culture of Participation. Chandos Publishing, 2009.

Frantz, P., \& Tucker-Raymond, C. "Integrating text messaging into reference services". Library HiTech News, 28.5(2011), 8 - 9.

Gapen, K. G. The virtual library: Knowledge, society, and the librarian. In: L.M. Saunders (Ed.), The Virtual Library: Visions and Realities, pp.1-14.Westport: Meckler, 1993.

Green, M. "Better, smarter, faster: Web 3.0 and the future of learning". Development and Learning in Organizations, 25.6 (2011).

Hendler, J. "Web 3.0 Emerging". Computer. 42.1 (2009), 111-113. 
Hermosa, Nemah N., and Audrey G. Anday. "Distance learning and digital libraries: The up open university experience." Journal of Philippine Librarianship 28.1 (2009).

Korićanin, Edin. „Razvoj virtuelnih okruženja i primena u elektronskom učenju.“ Доступно на: $\quad$ http://www.ftn.kg.ac.rs/download/SIR/SIREdinKoricanin (преузето 21.2.2017.)

Lancaster, F.W. Future Librarianship: preparing for an unconventional career. Wilson Library Bulletin, Vol.57.9 (1983), pp. 747-753.

Laurent, W. "Where We're Headed with Web 3.0: Not a gilded age or paradigm shift, but social interaction will increasingly drive business". Information Management, 20.4 (2010), 40.

Mason, David.. "Building Library 3.0: Issues in Creating a Culture of Participation". Electronic Library, 28.2, 2010, 347 - 348.

Massis, B. "QR codes in the library". New Library World, 112.9/10 (2011), 466 - 469.

Kaur, Amandeep."Role of Virtual Libraries in Learning Process." Handbook of Research on Inventive Digital Tools for Collection Management and Development in Modern Libraries. IGI Global, 2015. 42-52.

Nesta, F., \& Mi, J. “Library 2.0 or Library III: returning to leadership". Library Management, 3.1 (2011), $85-97$.

Pinto, M. \& Manso, R. "Virtual references services: defining the criteria and indicators to evaluate them". Electronic Library, 30.1 (2012), 51 - 69.

Rah, J., \& Gul, S., \& Wani, Z. “University libraries: step towards a web based knowledge management system". VINE, 40.1 (2010), $24-38$.

Romero, N. "Cloud computing in library automation. Benefits and drawbacks". The Bottom Line: Managing Library Finances, 25.3 (2012).

Urban, S. (2010). "Technology, cognition, and the academic librarian: a conference report". Library Hi Tech News, 27(4/5), 1 - 4.

Verma, Manoj Kumar, and N. K. Verma. "Concept of hybrid, digital and virtual library: a professional approach." InfoLib 7.14 (2014): 19-23.

Wilson, S., \& McCarthy, G. The mobile university: from the library to the campus. Reference Services Review, 38.2 (2010), 214 - 232.

Yang, S. (2012). “Move into the Cloud, shall we?”. Library Hi Tech News, 29(1), 4 - 7. 


\section{Bojana Trebinjac \\ University of Belgrade \\ Faculty of Philology}

\section{ROLE OF VIRTUAL LIBRARIES IN LEARNING PROCESS}

\section{Summary}

The advances in digital technologies continue to play a critical role in shaping the future of libraries. Now most libraries have maintained their virtual presence in addition to their physical asset. Almost all libraries have an appealing and elaborate website. In library and information science various terms are used to describe virtual libraries: digital libraries, electronic libraries, e-libraries, and the broader term virtual library. The term virtual library is used to describe any managed collection of information sources in an electronic format - text, image, audio, video, multimedia. Therefore, virtual libraries can include digital collections of book, newspapers, photographic document, cartographic material, printed music, sound recordings. This paper explores the advantages of virtual libraries for student learning, the types of learning that can be supported in virtual library environments, the importance of design to enable different types of learning, and the concerns posed by virtual libraries.

Key words: virtual libraries, digital libraries, digital collections, learning process, e-learning, technology enhanced learning 